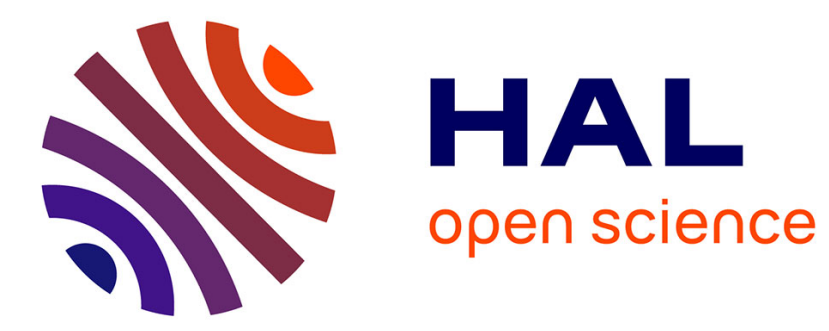

\title{
Safety with laser during retinal therapy: an electroretinographic study
}

\author{
E. El-Sayed, M. Talaat, A. Sallam
}

\section{To cite this version:}

E. El-Sayed, M. Talaat, A. Sallam. Safety with laser during retinal therapy: an electroretinographic study. Journal de Physique IV Proceedings, 1994, 04 (C4), pp.C4-270-C4-270. 10.1051/jp4:1994463 . jpa-00252726

\section{HAL Id: jpa-00252726 https://hal.science/jpa-00252726}

Submitted on 1 Jan 1994

HAL is a multi-disciplinary open access archive for the deposit and dissemination of scientific research documents, whether they are published or not. The documents may come from teaching and research institutions in France or abroad, or from public or private research centers.
L'archive ouverte pluridisciplinaire HAL, est destinée au dépôt et à la diffusion de documents scientifiques de niveau recherche, publiés ou non, émanant des établissements d'enseignement et de recherche français ou étrangers, des laboratoires publics ou privés. 


\title{
Safety with laser during retinal therapy: an electroretinographic study
}

\author{
E.M. EL-SAYED, M.S. TALAAT and A.M. SALLAM* \\ Physics Department, Faculty of Science, Ain Shams University, Cairo, Egypt \\ * Physics Department, Faculty of Science, Zagazig University, Benha, Egypt
}

Keywords : Ophthalmology, Retinal photocoagulation, ERG, Argon Laser, blood vessels.

\begin{abstract}
:
Studies of the retinal sensitivity, as reflected in the ERG records, have been made, before, during, and after exposure of the eye to an argon laser beam $(\lambda=$ $488 \mathrm{~nm}$; intensity $1 \mathrm{~mW} / \mathrm{cm}^{2}$; durations 0.12 and $0.25 \mathrm{sec}$ ). The applied retinal load thus was similar as that during retinal treatments. The ERG records were carried out at different temperatures $\left(10-30^{\circ} \mathrm{C}\right)$ for both light and dark adapted eyes.

The aim of this study was to assess the best suitable conditions for retinal laser treatments without affecting other retinal tissues. The obtained results showed that the argon laser therapy causes some damage to the eye which is paralleled by a noticeable change in the $b$-wave amplitude $\left(A_{b}\right)$ of the electroretinogram. This damage recovers faster when the laser dose and the eye temperature are reduced. Also it was preferable to perform these treatments in dark adapted eyes rather than in light adapted eyes.

Simple calculations of the changes in the external $\mathrm{K}^{+}$concentration, $\Delta \mathrm{K}$, induced by light stimulation were performed, before and after laser treatment, using Nernst equation modified by Miller relating $A_{b}$ to the logarithm of the external $\mathrm{K}^{+}$ concentration. This led to the conclusion that laser treatment has an indirect effect on the eye through its direct effects on the pigment epithelium and photoreceptor membrane permeabilities to $\mathrm{K}^{+}$. Moreover, calculations of the repair-damage ratio represented by $A_{b}$ variations, after laser exposure, helped for optimizing the laser conditions during treatments. This indicated that the ERG is a sensitive tool for studying the effects on the eye during treatments.
\end{abstract}

